\title{
DAMPAK KEBIJAKAN UPAH MINIMUM TERHADAP MIGRASI INTERNAL DI SULAWESI SELATAN
}

\author{
Ambar Dwi Santoso', Bonar M. Sinaga², Sri Hartoyo², dan M. Parulian Hutagaol ${ }^{2}$ \\ ${ }^{1}$ Pusdiklat BPS, Jagakarsa - Jakarta Selatan 12620, Jakarta \\ ${ }^{2}$ Fakultas Ekonomi dan Manajemen IPB, Darmaga 16680, Bogor \\ E-mail: ambardwisantoso@gmail.com
}

\begin{abstract}
ABSTRAK. Penelitian ini bertujuan menganalisis dampak kebijakan upah minimum terhadap migrasi internal. Analisis memfokuskan pada migrasi internal di Sulawesi Selatan dengan menggunakan data runtun-waktu 1995-2015. Analisis menggunakan model persamaan simultan dengan 55 persamaan struktural, dan estimasi dilakukan dengan metode Two Stage Least Squares (2SLS). Hasil menunjukkan kebijakan upah minimum meningkatkan arus migrasi masuk ke kawasan Makassar, dan dalam mengantisipasinya menjadi penting untuk meningkatkan pengeluaran pemerintah daerah guna penciptaan lapangan kerja baru pada kawasan di luar kawasan Makassar.
\end{abstract}

Kata kunci: model ekonometrika, upah minimum, migrasi internal, pengeluaran pemerintah daerah

\section{IMPACT OF MINIMUM WAGE POLICY ON INTERNAL MIGRATION IN SULAWESI SELATAN}

\begin{abstract}
The study aims to analyse the impact of minimum wage policy on internal migration. This analysis focuses on internal migration in Sulawesi Selatan by using time-series data 1995-2015. The simultaneous equations model consisting of 55 structural equations were employed and estimated by 2SLS method. The results confirm that the minimum wage policy led to increase migration flows to the region of Makassar, and to anticipate it is necessary to increase local government spending in regions outside of Makassar for creating new jobs.
\end{abstract}

Key words: econometric model, minimum wage, internal migration, local government spending

\section{PENDAHULUAN}

Sulawesi Selatan sedang mengalami proses transformasi, seperti Indonesia pada umumnya, perekonomian sedang beralih dari dominasi sektor pertanian di perdesaan menuju pangsa yang lebih besar pada kegiatan sektor non-pertanian di perkotaan (ILO 2015). Transformasi ekonomi prinsipnya adalah pembangunan ekonomi dan berkaitan erat dengan migrasi yakni menstransfer tenaga kerja (Lewis, 1954). Migrasi timbul karena perbedaan ekonomi dan mengalir dari suatu wilayah ke wilayah lain dengan kesempatan ekonomi yang lebih besar, seperti lebih banyak pekerjaan tersedia dan pendapatan/upah lebih tinggi. Perekonomian Sulawesi Selatan selama tahun 2011-2015 terus berkembang meski pertumbuhannya melambat dari tahun-tahun sebelumnya, pada tahun 2011 tumbuh 8,13 persen menurun menjadi 7,15 persen di tahun 2015 (BPS, 2016). Namun seiring pertumbuhan ekonomi, Bank Dunia (2016) menengarai bahwa ketimpangan di Indonesia semakin melebar yang disebabkan oleh salah satunya karena pekerjaan yang tidak merata. Permintaan pekerja terampil dengan upah tinggi di perkotaan meningkat, sedangkan sebagian besar pekerja tidak memiliki keterampilan sesuai yang dibutuhkan dan hanya tertampung dalam pekerjaan dengan produktivitas dan upah rendah. Faktor pekerjaan yang tidak merata menjadikan ketimpangan upah meningkat.

Upah minimum dapat menjadi instrumen kebijakan menurunkan ketimpangan upah dan meningkatkan pendapatan pekerja berpenghasilan rendah di bawah upah minimum. Rama (2001) menemukan bahwa kenaikan upah riil di Indonesia sebesar dua kali lipat pada paruh pertama tahun 1990-an mendorong kenaikan upah riil rata-rata sebesar 5-15 persen, dan menurunkan penyerapan tenaga kerja di daerah perkotaan hingga sebesar 5 persen. Chun dan Khor (2010) menunjukkan bahwa upah minimum di Indonesia berperan mengurangi ketimpangan upah dengan menaikkan tingkat upah pekerja di sektor formal.

Prinsip kebijakan upah minimum adalah memberikan perlindungan bagi pekerja untuk memperoleh upah yang layak dengan tetap memperhatikan faktor produktivitas dan kemajuan perusahaan (Izzaty dan Sari 2013). Mekanisme kelembagaan penetapan upah minimum di Indonesia telah mengalami beberapa kali perubahan, mulanya ditetapkkan oleh menteri kemudian didelegasikan kewenangan pada gubernur. Pada awalnya penentuan upah minimum didasarkan pada pemenuhan kebutuhan fisik minimum (KFM), kemudian diubah menjadi berdasarkan kebutuhan hidup minimum (KHM), dan selanjutnya kebutuhan hidup layak (KHL) (Pratomo dan Adi Saputra 2011). Perlambatan ekonomi global yang berimbas pada ekonomi nasional akibat penurunan harga-harga komoditas global dan penurunan ekspor (BI 2016; OECD 2016), mendorong pemerintah melakukan perubahan kebijakan sistem pengupahan dengan menerapkan sistem formula berdasarkan pada besaran inflasi dan pertumbuhan ekonomi nasional, yang dimaksudkan sebagai jaring pengaman untuk melindungi pekerja, dan menjadikan proses penetapan upah minimum 
lebih sederhana, adil dan terproyeksi serta berpihak pada pekerja karena memberi kepastian kenaikan upah minimum setiap tahunnya (Tim PresidenRI, 2016).

Penerapan sistem formula dengan besaran persentase yang sama secara nasional membawa konsekuensi berpotensi meningkatkan perbedaan upah minimum antarwilayah. Besaran kenaikan nominal upah minimum akan bervariasi karena besaran awalnya berbeda-beda. Provinsi, kabupaten/kota yang telah memiliki upah minimum lebih tinggi dari wilayah lain akan memperoleh kenaikan nominal yang lebih tinggi, dan sebaliknya. Di Sulawesi Selatan, secara umum berlaku upah minimum provinsi (UMP), dan terdapat tiga kabupaten/kota yang telah memberlakukan upah minimum kabupaten/ kota (UMK) yakni Kota Makassar, Kabupaten Pangkep, dan Kabupaten Luwu Timur. Karena ketentuan UMK nilainya lebih tinggi dari UMP dan UMK Kota Makassar adalah yang tertinggi, maka potensi kenaikan nominal upah minimum di kawasan Makassar berdasarkan kebijakan pengupahan sistem formula untuk tahun selanjutnya menjadi lebih tinggi dari kawasan lain di Sulawesi Selatan.

DalamprespektifHarris-Todaro(1970) peningkatan upah minimum sistem formula diduga meningkatkan pendapatan yang diharapkan dan akan mendorong migrasi internal antarwilayah di Sulawesi Selatan meningkat menuju ke daerah perkotaan di Kawasan Makassar. Bila migrasi masuk terus meningkat maka dapat menyebabkan surplus tenaga kerja meningkatkan pengangguran dan berimplikasi pada pertumbuhan ekonomi dan upaya pembangunan kawasan Makassar.

Tujuan yang ingin dicapai penelitian adalah untuk mengetahui dampak upah minimum terhadap migrasi internal antarwilayah di Sulawesi Selatan. Hasil analisis bermanfaat bagi pemerintah guna meninjau apakah kelembagaan pengupahan sistem formula mendukung arah pembangunan di Sulawesi Selatan.

\section{Hubungan Upah Minimum dan Migrasi}

Studi tentang upah minimum, umumnya berfokus pada dampak terhadap pekerjaan dan upah. Model neoklasik mendalilkan bahwa pada pasar tenaga kerja kompetitif dengan tenaga kerja homogen, upah minimum akan mengurangi jumlah pekerja dan meningkatkan pengangguran (Stigler 1946). Penerapam upah minimum menjadikan permintaan tenaga kerja menurun, sebaliknya penawaran tenaga kerja meningkat. Ukuran efek terhadap permintaan dan penawaran tenaga kerja bergantung pada elastisitasnya. Permintaan dan penawaran tenaga kerja yang lebih elastis terhadap perubahan upah dapat ditunjukan dengan kurva yang semakin datar. Melalui Gambar 1, Zavodny (2014) menggambarkan pengaruh dari upah minimum dan migrasi pada pasar tenaga kerja kompetitif. Panel (a) menunjukkan bahwa upah minimum $W_{u m}$, posisinya lebih tinggi dari upah keseimbangan $W^{*}$. Dengan adanya upah minimum, jumlah pekerja yang dibutuhan menjadi berkurang dari $L^{*}$ menjadi $L_{u m}$. Sebaliknya, penetapan upah minimum meningkatkan jumlah orang yang bersedia bekerja dari $L^{*}$ menjadi $L_{s}$. Karena jumlah pekerja yang dibutuhkan lebih sedikit dari jumlah orang yang bersedia bekerja, maka timbulah pengangguran yang besarnya sama dengan $L_{s}-L_{u m}$.

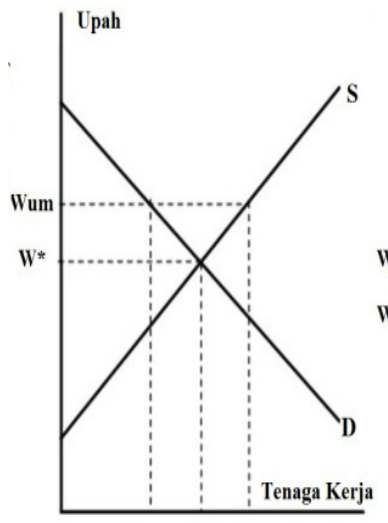

Lum $L^{*}$ Ln (a) Pengaruh Upah Minimum

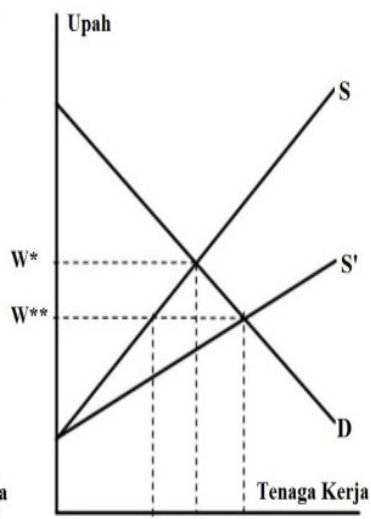

Ln $\mathrm{L}^{*} \mathrm{Li}+\mathrm{n}$ (b) Pengaruh Migrasi
Gambar 1. Pengaruh Upah Minimum dan Migrasi terhadap Pasar Tenaga kerja

Dengan asumsi pasar kompetitif dan tenaga kerja homogen, model neoklasik juga memprediksi migrasi menyebabkan menurunnya upah pekerja. Panel (b) memperlihatkan dampak peningkatan pasokan tenaga kerja akibat migrasi masuk. Misalkan kondisi awal tidak ada migran, semua tenaga kerja dipasok oleh penduduk asli. Migrasi masuk meningkatkan pasokan tenaga kerja dari $S$ ke $S$, berakibat menurunnya upah keseimbangan pasar dari $W^{*}$ menjadi $W^{* *}$. Penurunan upah mengurangi jumlah penduduk asli yang bersedia bekerja dari $L^{*}$ menjadi $L_{n}$. Dengan upah yang rendah, pengusaha bersedia dan mampu mempekerjakan pekerja $L_{i+n}$. Sedangkan jumlah pekerja migran sebanyak $L_{i+n}-L_{n}$. Penetapan upah minimum mengurangi dampak negatif migrasi masuk terhadap upah, namun meningkatkan efek negatif terhadap pengangguran (Zavodny 2014).

Hubungan kebijakan upah minimum dan migrasi tenaga kerja, pertama kali dihipotesiskan oleh HarrisTodaro (1970) dalam konteks negara-negara berkembang, di mana upah minimum diperkirakan menjelaskan tingginya tingkat pengangguran di perkotaan. Aspek kunci yang menjadi kerangka kerja adalah asumsi Todaro (1969) bahwa individu yang berencana untuk migrasi dari daerah perdesaan ke perkotaan terlebih dahulu membuat keputusan berdasarkan perbandingan besarnya penghasilan yang diharapkan di perkotaan dengan ratarata pendapatan yang diperoleh di desa. Model HarrisTodaro memprediksi migrasi terus mengalir dari daerah perdesaan ke daerah perkotaan sampai pada titik di mana upah minimum yang diharapkan di daerah perkotaan setara dengan pendapatan aktual yang dapat dicapai di sektor perdesaan. 


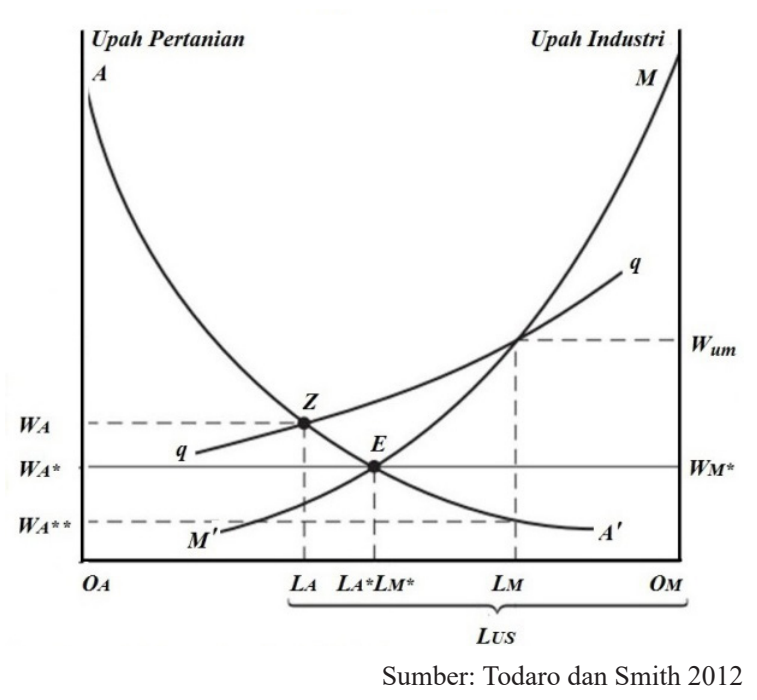

Gambar 2. Model Migrasi Harris-Todaro

Gambar 2 menunjukkan diagram model HarrisTodaro yang menjelaskan proses pencapaian titik keseimbangan pengangguran sehingga arus migrasi menuju kota berhenti (Todaro dan Smith, 2012). Model mengasumsikan perekonomian terdiri dari dua sektor, sektor pertanian di perdesaan dan sektor industri di perkotaan dengan total angkatan kerja yang tersedia sebanyak panjang garis $O_{A} O_{M}$. Kurva melengkung $A A^{\prime}$ menunjukkan tingkat permintaan tenaga kerja sektor pertanian, dan kurva melengkung $M M^{\prime}$ adalah tingkat permintaan tenaga kerja sektor industri.

Jika upah di sektor industri perkotaan ditetapkan sebesar $W_{u m}$ dan diasumsikan tidak ada pengangguran, maka tenaga kerja di sektor industri perkotaan sebanyak $O_{M} L_{M}$, sedangkan sisanya sebanyak $O_{A} L_{M}$ bekerja di sektor pertanian perdesaan dengan upah $O_{A} W_{A}^{* *}$. Kesenjangan tingkat upah terjadi antara desa dan kota sebesar $W_{u m}$ $W_{A}^{* *}$. Jika pekerja di perdesaan bebas melakukan migrasi, maka pekerja akan pergi ke kota untuk memburu upah yang lebih tinggi. Jika peluang mendapatkan pekerjaan yang diinginkan dinyatakan sebagai rasio antara penyerapan tenaga kerja sektor industri $L_{M}$, dan total angkatan kerja di perkotaan $L_{U S}$, maka $W_{A}=L_{M} / L_{U S}\left(W_{u m}\right)$ adalah nilai peluang mendapatan pekerjaan di perkotaan yang diperlukan untuk menyamakan tingkat pendapatan di perdesaan $W_{A}$, dengan tingkat pendapatan yang diharapkan di perkotaan sebesar $L_{M} / L_{U S}\left(W_{u m}\right)$ sehingga calon migran memiliki kesempatan sama untuk memilih lokasi pekerjaan pada titik-titik sepanjang kurva indiferen $q q$ '. Titik keseimbangan pengangguran baru sekarang berada pada titik Z, di mana kesenjangan upah riil kotadesa sebesar $W_{u m}-W_{A}$. Jumlah pekerja yang masih berada di sektor pertanian $O_{A} L_{A}$, dan $O_{M} L_{M}$ jumlah pekerja di sektor industri. Sisanya, $O_{M} L_{A}-O_{M} L_{M}$ yang menganggur atau terlibat dalam kegiatan sektor informal berpenghasilan rendah. Hal ini menjelaskan adanya pengangguran di daerah perkotaan dan rasionalitas ekonomi dari terus berlanjutnya migrasi desa-kota meskipun di perkotaan tingkat pengangguran tinggi.

\section{Studi Terdahulu}

Studi upah minimum di Indonesia umumnya berkaitan dengan upah, tenaga kerja, distribusi pendapatan, serta kemiskinan. Hasil penelitian kebanyakan menunjukkan bahwa penerapan upah minimum menurunkan permintaan tenaga kerja dan meningkatkan upah pekerja yang berada dibawah upah minimum, sesuai standar model ekonomi neoklasik. Chun dan Khor (2010) mendapatkan temuan bahwa kebijakan upah minimum berperan dalam mengurangi ketimpangan upah di Indonesia dengan menaikkan tingkat upah individu pekerja di sektor formal yang pada awalnya memiliki upah bulanan di bawah 90 persen dari garis upah minimum bulanan, namun tidak berpengaruh pada individu yang bekerja dengan upah bulanan di atas garis 90 persen dari upah minimum bulanan. Magruder (2013) dengan menggunakan data dari tahun 1990an di Indonesia, menunjukkan bahwa upah minimum dapat menjadi alat koordinasi untuk pengembangan menuju keseimbangan upah tinggi. Dengan menggunakan estimasi difference in spatial differences estimator diperoleh hasil adanya kecenderungan kuat kenaikan upah minimum mendukung model dorongan besar (big push): meningkatkan pekerjaan formal dan menurunkan pekerjaan informal sebagai respons terhadap kebijakan upah minimum, serta meningkatkan permintaan produk lokal. Namun menurut Bird dan Manning (2008) yang menganalisis keterkaitan upah minimum terhadap distribusi pendapatan dan kemiskinan berkesimpulan bahwa kenaikan upah minimum tidak efektif menjadi instrumen anti-kemiskinan di negara-negara berkembang seperti Indonesia. Hasil temuannya menunjukkan bahwa di antara orang miskin, kenaikan upah minimum hanya meningkatkan pendapatan bersih untuk 21 persen rumah tangga, sementara sisanya 79 persen rumah tangga mengalami kerugian.

Studi tentang upah minimum dan migrasi masih jarang ditemukan untuk kasus Indonesia. Giulietti (2015) merangkum bukti empiris dalam konteks Amerika Serikat bahwa penelitian tentang pengaruh upah minimum terhadap migrasi masih langka dan mencapai kesimpulan yang berbeda-beda. Namun terlepas dari temuan yang bervariasi, kebijakan upah minimum telah mempengaruhi arus migrasi serta pilihan lokasi.

Boffy-Ramirez (2013) menunjukkan bahwa pemilihan daerah tujuan migrasi sensitif terhadap perubahan upah minimum, dan dampaknya sangat bergantung pada lamanya seorang migran telah tinggal di Amerika Serikat. Temuan Boffy-Ramirez menunjukkan bahwa menaikkan upah minimum memiliki dampak positif pada upah migran dan tidak berpengaruh nyata terhadap pekerjaan seperti yang didalilkan model neoklasik. Kenaikan upah minimum yang lebih tinggi akan meningkatkan pendapatan yang diharapkan, dan menarik lebih banyak pekerja berpendidikan rendah masuk ke negara bagian tersebut. Giulietti (2014) melakukan studi fokus pada 
perubahan upah minimum federal Amerika Serikat untuk tahun 1996-1997 dan tahun 2007-2009, dan mendapatkan adanya efek magnet yang substansial, bahwa tingkat migrasi neto lebih tinggi di negara bagian di mana perubahan upah minimum lebih besar. Efek magnet yang terjadi menunjukkan ukuran yang cukup besar, seperti di New York upah yang diharapkan tumbuh 14,6 persen, tingkat migrasi netonya sekitar 0,61 persen, sementara di California upah yang diharapkan tumbuh 18 persen, tingkat migrasi netonya 0,80 persen. Analisis juga menunjukkan dampak keseluruhan kebijakan terhadap migran positif, bahwa perubahan upah minimum meningkatkan upah migran dan tidak menimbulkan konsekuensi pekerjaan.

Cadena (2014) meneliti dampak pasokan tenaga kerja lokal terhadap perubahan upah minimum atas respon dari keputusan pemilihan lokasi dari migran berketerampilan rendah. Candena mendapatkan aliran migran dari negara-negara bagian dengan upah minimum yang lebih tinggi mengurangi dampak negatif dari kebijakan mempekerjakan remaja pribumi, dan migran berketerampilan rendah cenderung tidak memilih negara dengan upah minimum yang lebih tinggi. Martin dan Termos (2015) meneliti respon migrasi terhadap variasi upah minimum negara bagian di Amerika Serikat, dan menemukan bahwa selisih satu dollar upah minimum riil antara dua daerah berkaitan dengan 3,1 persen lebih banyak pekerja berketerampilan rendah migrasi ke lokasi dengan upah minimum lebih rendah. Namun upah minimum tidak berpengaruh pada keputusan migrasi pekerja berketerampilan tinggi. Strobll dan Walsh (2016) dengan menggunakan data dari Thailand menunjukkan bahwa peningkatan migrasi berhubungan dengan peningkatan lebih tinggi secara proporsional pekerja yang bekerja dengan upah minimum relatif terhadap pekerja yang tidak mengikuti aturan upah minimum.

\section{METODE}

Penelitian ini menggunakan data runtun-waktu tahun 1995-2015 yang diperoleh dari beberapa sumber, seperti Badan Pusat Statistik (BPS), Kementerian Keuangan, Kementerian Tenaga Kerja. dan Badan Koordinasi Penanaman Modal (BKPM). Migrasi internal yang digunakan dalam penelitian ini adalah migrasi risen. Seseorang dikategorikan sebagai migran risen bilamana tempat tinggal sekarang berbeda dengan tempat tinggal pada waktu 5 tahun sebelumnya (BPS 2011).

Provinsi Sulawesi Selatan saat ini secara administratif terdiri dari 21 kabupaten dan 3 kota. Dalam penelitian ini Sulawesi Selatan dibagi dalam lima kawasan regional, yakni; Makassar, Parepare, Palopo, Bone, dan Bulukumba. Satu kawasan meliputi beberapa kabupaten/kota yang berdekatan dalam satu hamparan. Sehingga dalam kajian terdapat 20 arus migrasi asal-tujuan yang dibangun untuk menggambarkan arus migrasi internal di Sulawesi Selatan.
Untuk menganalisis dampak upah minimum terhadap migrasi internal di Sulawesi Selatan, dibangun model ekonometri sistem persamaan simultan dengan 55 persamaan struktural, terbagi dalam tiga blok, yakni blok migrasi 20 persamaan, blok pasar kerja 25 persamaan, dan blok output 10 persamaan. Estimasi model menggunakan metode Two Stages Least Squares (2SLS). Dalam kajian ini ditampilkan 30 persamaan terkait upah minimum dan migrasi, sebagai berikut:

\section{Persamaan Migrasi}

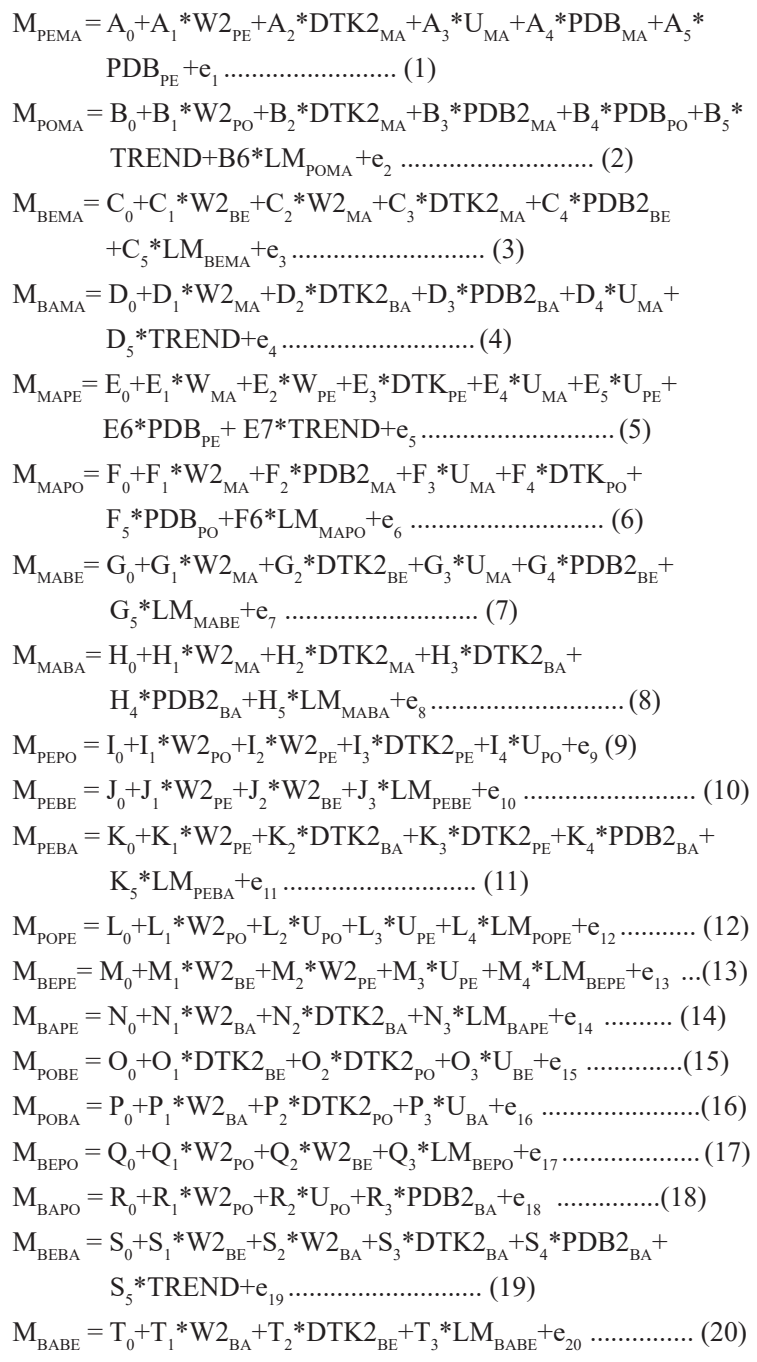

Persamaan Upah Tenaga Kerja:

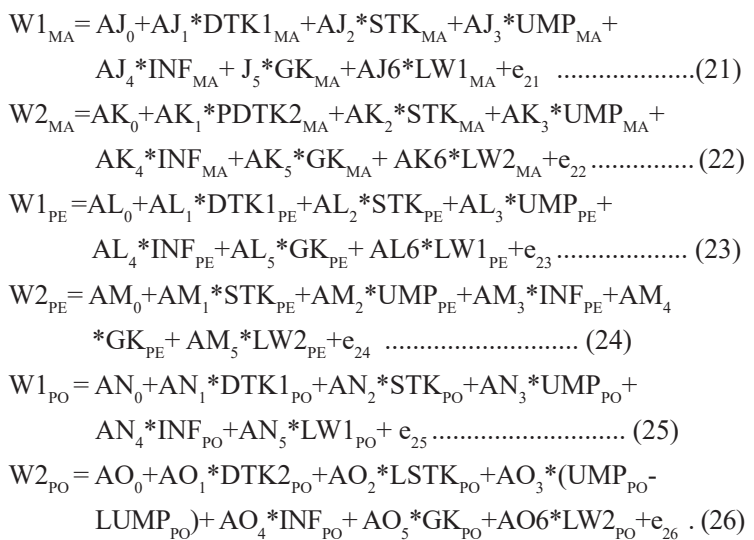




$$
\begin{aligned}
& \mathrm{W} 1_{\mathrm{BE}}=\mathrm{AP}_{0}+\mathrm{AP}_{1} * \mathrm{DTK} 1_{\mathrm{BE}}+\mathrm{AP}_{2} * \mathrm{LSTK}_{\mathrm{BE}}+\mathrm{AP}_{3} * \mathrm{UMP}_{\mathrm{BE}}+\mathrm{AP}_{4} \\
& * \mathrm{INF}_{\mathrm{BE}}+\mathrm{AP}_{5}^{*} \mathrm{GK}_{\mathrm{BE}}+\mathrm{AP} 6 * \mathrm{LW}_{\mathrm{BE}}+\mathrm{e}_{27} \text {.................. (27) } \\
& \mathrm{W} 2_{\mathrm{BE}}=\mathrm{AQ}_{0}+\mathrm{AQ}_{1} * \mathrm{STK}_{\mathrm{BE}}+\mathrm{AQ}_{2} * \mathrm{UMP}_{\mathrm{BE}}+\mathrm{AQ}_{3} * \mathrm{INF}_{\mathrm{BE}}+\mathrm{AQ}_{4} * \\
& \mathrm{GK}_{\mathrm{BE}}+\mathrm{AQ}_{5}{ }^{*} \mathrm{LW} 2_{\mathrm{BE}}+\mathrm{e}_{28} \text {......................... (28) } \\
& \mathrm{W} 1_{\mathrm{BA}}=\mathrm{AR}_{0}+\mathrm{AR}_{1} * \mathrm{PDTK}_{\mathrm{BA}}+\mathrm{AR}_{2} * \mathrm{LSTK}_{\mathrm{BA}}+\mathrm{AR}_{3} * \mathrm{UMP}_{\mathrm{BA}}+\mathrm{AR}_{4} \\
& * \mathrm{INF}_{\mathrm{BA}}+\mathrm{AR}_{5} * \mathrm{GK}_{\mathrm{BA}}+\mathrm{AR} 6 * \mathrm{LW}_{\mathrm{BA}}+\mathrm{e}_{29} \ldots \ldots \ldots \ldots \ldots \ldots \ldots . . .(29) \\
& \mathrm{W} 2_{\mathrm{BA}}=\mathrm{AS}_{0}+\mathrm{AS}_{1} * \mathrm{DTK} 2_{\mathrm{BA}}+\mathrm{AS}_{2} * \mathrm{STK}_{\mathrm{BA}}+\mathrm{AS}_{3} * \mathrm{UMP}_{\mathrm{BA}}+\mathrm{AS}_{4} \\
& * \mathrm{INF}_{\mathrm{BA}}+\mathrm{AS}_{5} * \mathrm{GK}_{\mathrm{BA}}+\mathrm{ASC}^{*} \mathrm{LW} 2_{\mathrm{BA}}+\mathrm{e}_{30} \ldots \ldots \ldots \ldots \ldots \ldots . . . . . . .(30)
\end{aligned}
$$

\section{Keterangan:}

M: Migrasi, W1: Upah Pertanian, W2: Upah Non Pertanian,

MA: Makassar, PE: Parepare, PO: Palopo, BE: Bone, BA: Bulukumba,

U: Pengangguran, STK: Angkatan Kerja, DTK1: Tenaga Pertanian, DTK2: Tenaga Non Pertanian,

PDB1: PDRB Pertanian, PDB2: PDRB Non Pertanian, UMP: Upah Minimum, GK: Garis Kemiskinan,

INF: Inflasi, LW1: Lag Upah Pertanian, LW2: Lag Upah Non Pertanian, LM: Lag Migrasi.

Kriteria statistik untuk validasi atas estimasi model ekonometrika digunakan Root Mean Squares Percent Error (RMSPE) dan Theil's Inequality Coefficient (U-Theil) (Koutsoyanis 1977). Kriteria statistik validasi yang menunjukan estimasi model yang baik adalah yang menghasilkan nilai RMSPE dan U-Theil yang semakin kecil. Koefisien U-Theil (U) berkisar antara 0 dan 1 . Jika nilai $U$ adalah 0 , itu berarti bahwa estimasi model sempurna, sedangkan jika $U$ adalah 1 , model ini dinilai naif (Pindyck dan Rubinfeld 1991).

Penelitian ini menggunaan simulasi historis (expost) pada periode 2011-2015 untuk mengevaluasi hasil kebijakan yang dapat berguna sebagai masukan kebijakan masa depan. Simulasi historis dalam kajian ini meliputi simulasi kebijakan peningatkan upah minimum dan peningkatan pengeluaran pemerintah daerah. Adapun alternatif simulasi kebijakan yang dilakukan adalah instrumen kebijakan yang mendorong tercapainya kebijakan migrasi internal dan pembangunan sebagai berikut:

S1= Kebijakan peningkatan upah minimum berdasarkan angka inflasi dan pertumbuhan ekonomi di provinsi Sulawesi Selatan,

S2 = Kebijakan peningkatan upah minimum berdasarkan angka inflasi dan pertumbuhan ekonomi di tingkat kawasan,

$\mathrm{S} 3=$ Kombinasi kebijakan peningkatan upah minimum berdasarkan angka inflasi dan pertumbuhan ekonomi di tingat kawasan dan peningkatan pengeluaran pemerintah daerah sebesar $25 \%$ di luar kawasan Makassar,

S4= Kombinasi Kebijakan peningkatan upah minimum berdasarkan angka inflasi dan pertumbuhan ekonomi di tingat kawasan dan peningkatan pengeluaran pemerintah daerah sebesar 25\% di seluruh kawasan.

\section{HASIL DAN PEMBAHASAN}

\section{Perkembangan Ekonomi dan Migrasi Internal}

Pembangunan ekonomi dalam prespektif Todaro (1969) berkaitan erat dengan migrasi, karena kemajuan ekonomi secara keseluruhan di banyak negara maju dapat dikarakteristikan oleh adanya proses realokasi sumberdaya yang berlangsung secara bertahap dari sektor pertanian ke sektor industri melalui migrasi dari desa ke kota (Todaro dan Smith 2012). Migrasi terjadi karena adanya perbedaan kemajuan atau kesempatan ekonomi antarwilayah, dan migrasi bergerak menuju wilayah yang memberikan kesempatan ekonomi yang lebih besar. Pembangunan ekonomi dikatakan mengalami pertumbuhan bila terjadi peningkatan kapasitas ekonomi dari tahun sebelumnya. Pembangunan ekonomi juga dapat diindikasikan melalui peningkatan kesempatan kerja dan berkurangnya pengganguran.

Tabel 1 menampilkan perkembangan PDRB, tenaga kerja, pengangguran, dan migrasi neto di Sulawesi Selatan memberi gambaran situasi pembangunan di Sulawesi Selatan, bahwa sektor non pertanian semakin terkonsentrasi di perkotaan kawasan Makassar dan sektor pertanian tetap berkembang di kawasan perdesaan. Kemajuan perkotaan kawasan Makassar ditunjukkan dengan perkembangan positif pertumbuhan ekonomi dan kesempatan kerja sektor non pertanian, dan perkembangan upah minimum.

Menurut Arman et.al (2016) meski pembangunan wilayah di Sulawesi Selatan menunjukkan asimetrik ekonomi, terkonsentrasi pada kawasan Makassar dominan pada sektor non pertanian, namun mengindikasikan adanya interaksi ekonomi dan konektivitas antara kawasan berbasis pertanian dengan kawasan non pertanian. Sektor pertanian menjadi sektor basis yang sensitif, kelebihan produksi, memberi pasokan dan banyak digunakan

\begin{tabular}{|c|c|c|c|c|c|c|}
\hline \multirow{2}{*}{ Kawasan } & \multicolumn{2}{|c|}{ PDRB } & \multicolumn{2}{|c|}{$\begin{array}{l}\text { Tenaga } \\
\text { Kerja }\end{array}$} & \multirow{2}{*}{$\begin{array}{c}\text { Pengangguran } \\
(\%)\end{array}$} & \multirow{2}{*}{$\begin{array}{l}\text { NM } \\
\text { (org) }\end{array}$} \\
\hline & $\begin{array}{c}\mathrm{P} \\
(\%)\end{array}$ & $\begin{array}{l}\mathrm{NP} \\
(\%)\end{array}$ & $\begin{array}{c}\mathrm{P} \\
(\%)\end{array}$ & $\begin{array}{l}\mathrm{NP} \\
(\%)\end{array}$ & & \\
\hline Makassar & 4.0 & 41.4 & 6.7 & 28.2 & 51.7 & 35995 \\
\hline Parepare & 5.3 & 7.2 & 5.2 & 6.0 & 9.8 & -6313 \\
\hline Palopo & 5.5 & 12.0 & 11.2 & 8.1 & 17.5 & -11057 \\
\hline Bone & 5.9 & 8.2 & 9.7 & 7.5 & 12.6 & -12155 \\
\hline Bulukumba & 4.5 & 6.0 & 9.0 & 8.4 & 8.4 & -6470 \\
\hline Total & 25.2 & 74.8 & 41.8 & 58.2 & 100.0 & \\
\hline
\end{tabular}
sektor lain di kawasan asal dan kawasan lain. Sedangkan sektor non pertanian menjadi sektor strategis, sensitif terhadap permintaan akhir dan responsif mendorong perekonomian, memiliki konektivitas dengan beragam sektor di kawasan asal dan kawasan lain.

Tabel 1. Distribusi PDRB, Tenaga Kerja, Pengangguran, Migrasi Neto di Sulawesi Selatan Tahun 2015

Ket: $\mathrm{P}=$ Pertanian, $\mathrm{NP}=$ Non Pertanian, $\mathrm{NM}=$ Migrasi Neto Sumber: BPS, diolah 
Gambar 3 memperlihatkan dalam beberapa tahun terakhir pertumbuhan ekonomi sektor pertanian mengalami tren meningkat, sejalan dengan sektor non pertanian meski tingkat pertumbuhannya masih lebih tinggi dari sektor pertanian. Hal berbeda terjadi pada penciptaan kesempatan kerja, pertumbuhan tenaga kerja pertanian menunjukan tren menurun bahkan negatif, dan pertumbuhannya selalu lebih rendah dari pertumbuhan tenaga kerja non pertanian. Perkembangan ekonomi dan kesempatan kerja sektor pertanian yang terjadi di Sulawesi Selatan tampak sejalan dengan temuan Adriani dan Wildayana (2015) bahwa pembangunan ekonomi sektor pertanian tidak diikuti dengan penciptaan kesempatan kerja baru di sektor pertanian, dan pembangunan sektor pertanian tampak lebih diarahkan pada kegiatan yang padat modal daripada padat karya.

Bagi sektor pertanian, berkurangnya kesempatan kerja sektor pertanian berimplikasi meningkatnya kelebihan tenaga kerja sektor pertanian dapat menyebabkan penurunan produktivitas sektor pertanian dan meningkatnya pengangguran. Antisipasi atas kelebihan tenaga kerja sektor pertanian adalah migrasi ke kawasan sektor non pertanian, mengingat karena kesempatan kerja yang lebih banyak di sektor non pertanian dan tren positif upah minimum.

Gambar 3. Pertumbuhan PDRB, tenaga Kerja, Upah Minimum, Pengangguran dan Migrasi Neto Kawasan Makasar di Sulawesi Selatan Tahun 2001-2015

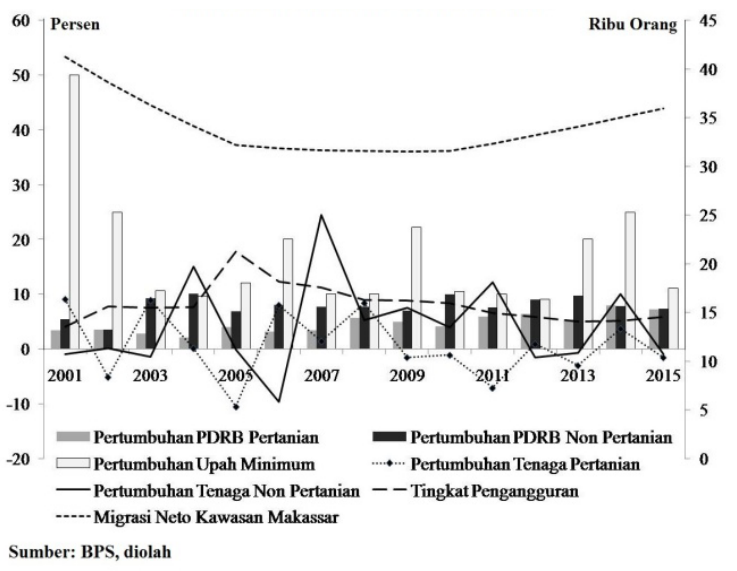

Peninjauan migrasi secara spasial menjadi penting karena arus distribusi penduduk yang tidak merata. Tabel 1 memperlihatan kesenjangan distribusi migran, migrasi neto kawasan Makassar positif sedangkan pada kawasan lain negatif. Migrasi neto yang positif diantara kawasan lain adalah indikasi besarnya arus migrasi masuk. Perkembangan migrasi neto di kawasan Makassar tampaknya sejalan dengan kemajuan ekonomi kawasan Makassar (Nyompa et.al, 2012), dan menunjukkan kesesuaian dengan model Todaro bahwa tingginya arus migrasi dari kawasan pinggiran perdesaan menuju ke kawasan perkotaan lebih disebabkan tingginya intensitas pembangunan ekonomi di wilayah perkotaan, dan sebagai fenomena ekonomi dengan keputusan rasional migrasi akan terus terjadi dan mengalir menuju daerah kota meski tingkat penganggurannya tinggi.

Arus migrasi yang terus meningkat, menyebabkan surplus tenaga kerja dan meningkatkan pengangguran, seperti di kawasan Makassar yang memiliki jumlah pengangguran terbanyak, lebih dari separuh pengangguran di Sulawesi Selatan. Tren meningkatnya arus migrasi masuk ke kawasan Makassar menjadi kurang baik bagi upaya distribusi penduduk dan pembangunan. Perubahan pola mobilitas penduduk di masa datang penting diupayakan guna mencapai distribusi mobilitas penduduk yang seimbang, dan kesuksesannya bergantung pada perkembangan kawasan lain di luar kawasan Makassar.

\section{Hasil Estimasi Model Ekonomi Migrasi}

Model dibangun dalam penelitian ini telah mengalami beberapa kali respesifikasi degan menggunakan program SAS dengan prosedur SYSLIN, dan dianggap sudah memenuhi kriteria ekonomi dan statistik. Hasil estimasi parameter telah menunjukkan bahwa seluruh variabel penjelas memiliki tanda parameter estimasi sesuai hipotesis dan teori ekonomi. Berdasarkan kriteria statistik, nilai koefisien determinasi $\left(\mathrm{R}^{2}\right)$ secara umum cukup besar, lebih dari 0.9, yang menunjukkan bahwa variabel-variabel penjelas yang terdapat di dalam model mampu menjelaskan fluktuasi setiap variabel endogen secara baik. Sedangkan nilai uji F, sebagian besar bernilai Prop $>F$ bernilai $<.0001$, menunjukkan bahwa secara bersama-sama semua variabel penjelas dapat menjelaskan variabel endogen secara nyata. Tabel 2 menampilkan hasil estimasi parameter beberapa faktor yang mempengaruhi banyaknya migrasi masuk ke kawasan Makassar dari kawasan lain di Sulawesi Selatan, yang merupakan bagian dari 20 persamaan struktural dalam blok migrasi.

Berdasarkan hasil estimasi dalam Tabel 2, migrasi masuk ke kawasan Makassar berhubungan positif dengan kesempatan kerja dan upah non pertanian di kawasan Makassar, sedangkan pengangguran di kawasan Makassar berhubungan negatif terhadap migrasi masuk ke kawasan Makassar. Hal tersebut menunjukkan bahwa motif ekonomi seperti disebut Todaro (1980) relevan sebagai faktor yang mendasari motivasi bagi sebagian penduduk kawasan lain untuk pindah menuju ke kawasan Makassar. Migrasi ke kawasan Makassar mempunyai dua harapan, yaitu memperoleh pekerjaan dan harapan mendapatkan pendapatan yang lebih tinggi dari pada yang diperoleh di kawasan asal. Selain, faktor kesempatan kerja dan upah, migrasi juga dipengaruhi oleh dayatarik kawasan, tercermin dari besarnya nilai PDRB yang menggambarkan besarnya kegiatan ekonomi kawasan. Migrasi masuk ke kawasan Makassar secara umum berhubungan positif dengan besaran PDRB kawasan Makassar. 
Tabel 2. Hasil Estimasi Persamaan Migrasi Masuk Kawasan Makassar

\begin{tabular}{|c|c|c|}
\hline Nama Variabel & Parameter & $\operatorname{Pr}>|t|$ \\
\hline \multicolumn{3}{|l|}{ Migrasi dari Parepare ke Makassar } \\
\hline Intersep & 15558.94 & $<.0001$ \\
\hline Upah non pertanian Parepare & -0.02117 & $<.0001$ \\
\hline Tenagakerja non pertanian Makassar & 0.006768 & 0.1087 \\
\hline Pengangguran Makassar & -0.00293 & 0.6412 \\
\hline PDRB Makassar & 0.065223 & 0.8143 \\
\hline PDRB Parepare & 0.346315 & 0.7223 \\
\hline $\mathrm{R}^{2}=0.93401 \quad \mathrm{~F}=39.63(<.0001)$ & \multicolumn{2}{|c|}{$\mathrm{DW}=1.1047$} \\
\hline \multicolumn{3}{|l|}{ Migrasi dari Palopo ke Makassar } \\
\hline Intersep & 2879.518 & 0.3708 \\
\hline Upah non pertanian Palopo & -0.00049 & 0.6217 \\
\hline Tenagakerja non pertanian Makassar & 0.003838 & 0.0857 \\
\hline PDRB non pertanian Makassar & 0.540835 & 0.0852 \\
\hline PDRB Palopo & -0.09321 & 0.7238 \\
\hline Tren waktu & -619.559 & 0.0609 \\
\hline $\begin{array}{l}\text { Lag Migrasi dari Palopo ke } \\
\text { Makassar }\end{array}$ & 0.623192 & 0.0143 \\
\hline $\mathrm{R}^{2}=0.98825 \quad \mathrm{~F}=182.28(<.0001)$ & \multicolumn{2}{|c|}{$\mathrm{DW}=1.4901$} \\
\hline \multicolumn{3}{|l|}{ Migrasi dari Bone ke Makassar } \\
\hline Intersep & 5562.971 & 0.2659 \\
\hline Upah non pertanian Bone & -0.03549 & 0.0217 \\
\hline Upah non pertanian Makassar & 0.029157 & 0.1054 \\
\hline Tenagakerja non pertanian Makassar & 0.005626 & 0.3743 \\
\hline PDRB non pertanian Bone & -1.91853 & 0.1042 \\
\hline Lag Migrasi dari Bone ke Makassar & 0.678944 & $<.0001$ \\
\hline $\mathrm{R}^{2}=0.93697 \quad \mathrm{~F}=41.62(<.0001)$ & \multicolumn{2}{|c|}{$\mathrm{DW}=1.7192$} \\
\hline \multicolumn{3}{|l|}{$\begin{array}{l}\text { Migrasi dari Bulukumba ke } \\
\text { Makassar }\end{array}$} \\
\hline Intersep & 9852.593 & 0.047 \\
\hline Upah non pertanian Makassar & 0.062193 & 0.0002 \\
\hline $\begin{array}{l}\text { Tenagakerja non pertanian } \\
\text { Bulukumba }\end{array}$ & -0.01224 & 0.6306 \\
\hline PDRB non pertanian Bulukumba & -4.97556 & 0.093 \\
\hline Pengangguran Makassar & -0.02032 & 0.1764 \\
\hline Tren waktu & -920.274 & 0.0901 \\
\hline $\mathrm{R}^{2}=0.92032 \quad \mathrm{~F}=32.34(<.0001)$ & \multicolumn{2}{|c|}{$\mathrm{DW}=1.4474$} \\
\hline
\end{tabular}

Sumber: Hasil pengolahan

\section{Dampak Kebijakan Upah Minimum}

Kemampuan prediksi model yang digunakan dalam penelitian ini telah divalidasi dengan simulasi dasar untuk periode 2011-2015. Hasil validasi diperoleh 93.69 persen persamaan struktural mempunyai nilai RMSPE di bawah 30 persen dan 97.3 persen persamaan struktural mempunyai nilai U-Theil di bawah 0.2. Hal ini menunjukan bahwa model yang dibangun dan telah diestimasi memiliki nilai variabel hasil prediksi cukup dekat dengan nilai aktualnya, kriteria model yang baik terpenuhi. Dengan demikian model dapat digunakan untuk analisis simulasi historis.

Simulasi historis dalam kajian ini meliputi simulasi kebijakan peningkatan upah minimum dan pengeluaran pemerintah daerah. Simulasi kebijakan upah minimum dilakukan dengan menerapkan pengupahan sistem formula dimana perhitungannya adalah $\mathrm{UM}_{\mathrm{n}}=\mathrm{UM}_{\mathrm{t}}+\left\{\mathrm{UM}_{\mathrm{t}} *\left(\right.\right.$ Inflasi $_{\mathrm{t}}+$ DeltaPDB $\left.\left._{\mathrm{t}}\right)\right\}$, yang mengisyaratkan kenaikan persentase upah minimum pada tingkat yang sama secara nasional. Pada kenyataannya, terdapat perbedaan antarwilayah dalam hal pertumbuhan ekonomi dan inflasi. Pada penelitian ini, simulasi pertama (S1) adalah peningkatan peningkatan upah minimum dilakukan berdasarkan pertumbuhan ekonomi dan inflasi di tingkat provinsi Sulawesi Selatan, dan sebagai pembanding dilakukan simulasi kedua (S2) peningkatan upah minimum berdasarkan pertumbuhan ekonomi dan inflasi tiap kawasan.

Pilihan simulasi kebijakan tunggal S1 didasarkan pada Peraturan Pemerintah nomor 78 tahun 2015, yakni peningatan upah minimum berdasarkan angka inflasi dan pertumbuhan ekonomi yang sama, hanya saja yang menjadi dasar hitung dalam kajian ini adalah inflasi dan pertumbuhan ekonomi Sulawesi Selatan, yang sesungguhnya dasar hitung adalah inflasi dan pertumbuhan ekonomi nasional. Berdasarkan Tabel 3, hasil S1 berdampak terhadap peningkatan upah yang diterima pekerja rata-rata sebesar 2.91 persen. Peningkatan upah tersebut direspon oleh para pengusaha dan menyebabkan permintaan tenaga kerja menurun sebesar 0.82 persen. Hasil simulasi peningkatan upah minimum ini secara umum sejalan dengan model neoklasik, yakni meningkatkan upah rata-rata dan menurunkan permintaan tenaga kerja.

Namun secara spasial peningkatan upah minimum direspon beragam. Pada kawasan Makassar, hasil simulasi S1 berdampak paling besar, meningkatkan upah rata-rata 5.04 persen, dan menurunkan kesempatan kerja sebesar 2.12 persen. Sedangkan dampak terendah terjadi di kawasan Bulukumba, dimana simulasi S1 hanya meningkatkan upah sebesar 0.9 persen, dan menurunkan kesempatan kerja sebanyak - 0.03 persen.

Perbedaan peningkatan upah antarkawasan ini menjadikan meningkatnya perbedaan upah, dan mendorong arus migrasi menuju kawasan yang memiliki upah yang tinggi. Migrasi masuk ke kawasan Makassar meningkat 2.68 persen, sedangkan migrasi keluar dari kawasan Makassar menurun -2.18 persen. Sehingga migrasi neto ke kawasan Makassar bernilai positif meningkat sebanyak 2211 orang dari semula 35585 orang meningkat menjadi 37796 orang. Hal serupa juga terjadi di kawasan Palopo, migrasi masuk meningkat 0.25 persen dan migrasi keluar menurun -4.28 persen, namun net migrasi masih bernilai negatif, hanya bekurang 992 orang dari semula sebesar -5533 orang menjadi -4541 orang.

Pada kawasan Bulukumba, meksi respon peningkatan upah dan penciptaan kesempatan kerja adalah yang terendah, namun respon migrasinya tampak nyata. Peningkatan upah minimum S1, meningkatkan migrasi masuk sebesar 1.98 persen dan juga meningkatkan migrasi keluar sebesar 10.45 persen. Sehingga migrasi netonya yang negatif bertambah sebanyak -1746 orang dari -9839 orang turun menjadi -11586 orang.

Untuk kawasan Bone, peningkatan upah minimum S1 menurunkan migrasi masuk sebesar -2.58 persen dan meningkatkan migrasi keluar sebesar 2.86 persen

Sehingga migrasi netonya yang negatif bertambah sebanyak -881 orang dari -14171 orang turun menjadi 
-15051 orang. Sementara pada kawasan Parepare, simulasi S1 berdampak menurunkan migrasi masuk sebesar -11.31 persen dan migrasi keluar sebesar -4.43 persen, dan migrasi netonya yang negatif bertambah -567 orang menjadi -6618 orang dari sebelumnya -6043 orang.

Secara umum, dampak peningkatan upah minimum terhadap migrasi internal di Sulawesi Selatan sejalan anggapan Harris-Todaro (1970) dan temuan BoffyRamirez (2013) bahwa kenaikan upah minimum yang tinggi akan meningkatkan pendapatan yang diharapan calon migran dan menarik lebih banyak migran.

Tabel 3. Dampak Upah Minimum dan Pengeluaran Pemerintah Daerah Terhadap Upah, Tenaga kerja, Output dan Migrasi

\begin{tabular}{|c|c|c|c|c|c|}
\hline \multirow{2}{*}{$\begin{array}{l}\text { Variabel/ } \\
\text { Kawasan }\end{array}$} & \multirow{2}{*}{ Nilai Dasar } & \multicolumn{4}{|c|}{ Perubahan } \\
\hline & & S1 & $\mathrm{S} 2$ & $\mathrm{~S} 3$ & S4 \\
\hline Upah & (Rupiah) & \multicolumn{4}{|c|}{$(\%)$} \\
\hline Total & 443783 & 2.91 & 2.86 & 3.44 & 3.44 \\
\hline Makassar & 491595 & 5.04 & 4.85 & 4.85 & 4.86 \\
\hline Parepare & 424297 & 4.08 & 4.03 & 4.64 & 4.64 \\
\hline Palopo & 584505 & 1.42 & 1.42 & 2.92 & 2.92 \\
\hline Bone & 376465 & 2.93 & 2.96 & 2.98 & 2.98 \\
\hline Bulukumba & 342054 & 0.96 & 0.94 & 1.32 & 1.32 \\
\hline Tenagakerja & (Orang) & \multicolumn{4}{|c|}{$(\%)$} \\
\hline Total & 3331096 & -0.82 & -0.80 & 1.60 & 2.15 \\
\hline Makassar & 1183477 & -2.12 & -2.04 & -2.04 & -0.50 \\
\hline Parepare & 378666 & -0.07 & -0.06 & 4.08 & 4.08 \\
\hline Palopo & 618721 & -0.04 & -0.04 & 3.56 & 3.56 \\
\hline Bone & 577409 & -0.28 & -0.29 & 3.42 & 3.42 \\
\hline Bulukumba & 572823 & -0.03 & -0.03 & 3.54 & 3.54 \\
\hline Output/PDRB & (Miyar) & \multicolumn{4}{|c|}{$(\%)$} \\
\hline Total & 61942.7 & -1.34 & -1.30 & 1.21 & 2.57 \\
\hline Makassar & 28609.8 & -2.78 & -2.68 & -2.68 & 0.27 \\
\hline Parepare & 7950.1 & -0.01 & -0.01 & 0.68 & 0.68 \\
\hline Palopo & 11716.4 & -0.06 & -0.06 & 6.25 & 6.25 \\
\hline Bone & 7654.5 & -0.38 & -0.39 & 6.75 & 6.75 \\
\hline Bulukumba & 6011.9 & 0.00 & 0.00 & 3.55 & 3.55 \\
\hline Migrasi Masuk & (Orang) & \multicolumn{4}{|c|}{$(\%)$} \\
\hline Makassar & 61457 & 2.68 & 2.50 & -1.67 & 0.89 \\
\hline Parepare & 12251 & -11.31 & -11.09 & 4.62 & 2.98 \\
\hline Palopo & 16679 & 0.25 & 0.19 & 5.14 & 3.40 \\
\hline Bone & 8724 & -2.58 & -2.65 & 3.40 & 3.00 \\
\hline Bulukumba & 8487 & 1.98 & 1.80 & 7.43 & 3.89 \\
\hline Migrasi Keluar & (Orang) & \multicolumn{4}{|c|}{$(\%)$} \\
\hline Makassar & 25872 & -2.18 & -2.06 & 6.10 & 2.91 \\
\hline Parepare & 18293 & -4.43 & -4.37 & -3.90 & -2.69 \\
\hline Palopo & 22211 & -4.28 & -4.16 & -2.36 & 1.23 \\
\hline Bone & 22894 & 2.86 & 2.40 & -3.02 & -2.23 \\
\hline Bulukumba & 18326 & 10.45 & 10.04 & 9.15 & 11.18 \\
\hline Migrasi Neto & (Orang) & \multicolumn{4}{|c|}{ (Orang) } \\
\hline Makassar & 35585 & 2211 & 2073 & -2604 & -205 \\
\hline Parepare & -6043 & -576 & -560 & 1280 & 857 \\
\hline Palopo & -5533 & 992 & 956 & 1382 & 294 \\
\hline Bone & -14171 & -881 & -781 & 989 & 772 \\
\hline Bulukumba & -9839 & -1746 & -1688 & -1046 & -1718 \\
\hline
\end{tabular}

Keterangan :

$\mathrm{S} 1$ = Kebijakan tunggal upah minimum berdasarkan angka provinsi,

S2 = Kebijakan tunggal upah minimum berdasarkan angka kawasan,

S3 = Kebijaan kombinasi upah minimum berdasarkan angka kawasan dan pengeluaran pemerintah daerah sebesar $25 \%$ di luar kawasan Makassar,

$\mathrm{S} 4=$ Kebijkan kombinasi upah minimum berdasarkan angka kawasan dan pengeluaran pemerintah daerah sebesar $25 \%$ di seluruh kawasan.

Sumber: Hasil pengolahan
Penurunan permintaan tenaga kerja akibat kebijakan upah minimum, secara umum menjadikan output menurun sebesar -1.34 persen atau sebesar -832 milyar rupiah. Penurunan output tertinggi terjadi pada kawasan Makassar -2.78 persen atau -794.6 milyar rupiah, diikuti berturut-turut kawasan Bone sebesar -0.38 persen atau 29.2 milyar rupiah, kawasan Palopo sebesar -0.06 persen atau -7.4 milyar rupiah.

Hasil simulasi S1 ini tidak menguntungkan jika yang diharapkan adalah untuk mengurangi arus migrasi menuju ke kawasan Makassar dalam upaya menyeimbangkan distribusi penduduk dan pembangunan. Kebijakan S1 secara umum, meningkatkan arus migrasi masuk ke kawasan Makassar, menjadikan kesempatan kerja berkurang dan menyebabkan output menurun. Kebijakan S1 hanya menguntungkan pekerja yang dapat menikmati peningkatan upah, sementara sebagian tenaga kerja lainnya dirugikan karena berkurangnya kesempatan kerja akibat rasionalisasi oleh para pengusaha.

Ada dua kemungkinan yang perlu diperhatikan dengan penerapan kebijakan S1 sehingga secara umum tidak menguntungkan bagi pembangunan dan distribusi penduduk di Sulawesi Selatan, pertama kemungkinan penggunaan persentase kenaikan yang sama akibat kebijakan tunggal penggunaan satu angka inflasi dan pertumbuhan ekonomi, yang mengakibatkan variasi antarkawasan menjadi semakin besar. Kedua, kesenjangan pembangunan antarkawasan sejatinya telah ada di Sulawesi Selatan, bahwa kawasan Makassar memiliki skala ekonomi yang lebih besar dari kawasan lainnya, sedangkan kebijakan upah minimum cenderung berlaku untuk sektor formal yang ada di kawasan perkotaan. Dengan demikian kawasan Makassar memiliki keuntungan lebih dari kawasan lain, sehingga menambah besarnya dayatarik kawasan bagi penduduk kawasan lain untuk bermigrasi ke kawasan Makassar.

Simulasikedua(S2)adalah kebijakanmeningkatkan upah minimum berdasarkan pada angka pertumbuhan ekonomi dan inflasi di tiap kawasan. Simulasi S2 ini dilakukan dengan maksud sebagai pembanding S1 guna mengevaluasi besaran tunggal kenaikan upah minimum dengan menerapkan kebijakan peningkatan upah minimum berdasarkan angka inflasi dan pertumbuhan ekonomi masing-masing kawasan dengan harapan peningkatan upah minimum sesuai dengan kemampuan kawasan itu sendiri.

Hasil simulasi S2 menunjukkan hasil yang serupa dengan S1, namun besarannya berbeda, dimana penurunan permintaan tenaga kerja dan output serta arus migrasi besarannya lebih kecil dari S1. Secara umum, peningkatan upah yang diterima pekerja menurun menjadi sebesar 2.68 persen dari sebelumnya S1 sebesar 2.91 persen. Permintaan tenaga kerja menurun menjadi sebesar -0.80 persen, dan penurunan output sebesar -1.3 persen. Hasil S2 menunjukkan respon dan kapasitas ekonomi masing-masing kawasan. 
Hasil simulasi kebijakan tunggal S2, yakni peningkatan upah minimum berdasar pada keragaman wilayah juga tidak menguntungkan jika tujuan yang diharapkan adalah untuk mengurangi arus migrasi menuju ke kawasan Makassar dalam upaya menyeimbangkan distribusi penduduk dan pembangunan.

Padakenyataannya, kebijakan tunggal peningkatan upah minimum tidak dapat dijalankan secara utuh, namun selalu dijalankan bersamaan dengan kebijakan lainnya. Kebijakan peningkatan upah minimum sebagai bagian kebijakan pemerintah yang tetap secara teratur dievaluasi besarannya menjadi tidak mungkin dihindari. Oleh karena itu, kebijakan kombinasi menjadi alternatif untuk mencapai tujuan yang diinginkan.

Mempertimbangkan latar belakang masalah kondisi struktur ekonomi yang berbeda antara kawasan Makassar dan kawasan lainnya di Sulawesi Selatan dan kecenderungan arus migrasi internal menuju ke kawasan Makassar, maka perlu dilakukan afirmasi pemihakan terhadap kawasan di luar kawasan Makassar dengan tujuan untuk mencapai keseimbangan distribusi penduduk dan pembangunan yang lebih baik. Bentuk afirmasi yang memunginkan dilakukan salah satunya adalah peningkatan alokasi pengeluaran pemerintah daerah pada kawasan selain kawasan Makassar (Santoso et.al, 2017).

Simulasi ketiga (S3) adalah kombinasi peningkatan upah minimum berdasarkan angka pertumbuhan ekonomi dan inflasi masing-masing kawasan dan peningkatan pengeluaran pemerintah daerah sebesar 25 persen untuk kawasan di luar kawasan Makassar, sebagai instrumen afirmatif untuk meningkatkan pemerataan distribusi penduduk dan pembangunan di Sulawesi Selatan. Sebagai pembanding, dilakukan simulasi keempat (S4) yakni kombinasi peningkatan upah minimum berdasarkan angka pertumbuhan ekonomi dan inflasi masing-masing kawasan dan peningkatan pengeluaran pemerintah daerah sebesar 25 persen untuk seluruh kawasan.

Hasil simulasi S3 kombinasi kebijakan upah minimum dan pengeluaran pemerintah daerah berdampak positif. Kebijakan peningkatan pengeluaran pemerintah daerah dapat meningkatkan output dan kesempatan kerja, dan mampu meredam dampak negatif dari kebijakan upah minimum.

Kebijakan S3 meningkatkan upah rata-rata sebesar 3.44 persen, peningkatan upah tertinggi di kawasan Makassar 4.85 persen dan terendah kawasan Bulukumba 1.32 persen. Hasil S3 juga berdampak pada kesempatan tenaga kerja secara umum meningkat sebesar 1.6 persen. Namun secara spasial dampak kebijakan S3 beragam, kawasan Makassar masih mengalami penurunan kesempatan kerja sebesar -2.04 persen, sementara pada kawasan lain meningkat antara 3 persen hingga 4 persen. Pola yang sama juga terjadi pada output, secara umum meningkat sebesar 1.21 persen, namun output kawasan Makassar menurun sebesar -2.68 persen, sementara pada kawasan lain mengalami peningkatan. Peningkatan output terbesar pada kawasan Bone 6.75 persen, dan terendah kawasan Parepare 0.68 persen.

Dampak dari kebijakan S3 pada migrasi menunjukkan hasil positif, bilamana yang menjadi tujuan adalah menurunkan laju arus migrasi masuk ke kawasan Makassar. Kebijakan S3 berdampak menurunkan migrasi masuk ke kawasan Makassar sebesar -1.67 persen dan meningkatkan migrasi keluar kawasan Makassar sebesar 6.1 persen. Pada kawasan lain, S3 berdampak meningkatkan migrasi masuk antara 3.4 persen di kawasan Bone hingga 7.43 persen di kawasan Bulukumba, dan menurunkan migrasi keluar pada kawasan Parepare -3.9 persen, kawasan Palopo -2.36 persen, dan kawasan Bone -3.02 persen. Sedangkan di kawasan Bulukumba, kebijakan S3 meningkatkan migrasi keluar sebesar 9.15 persen.

Akhirnya, kebijakan S3 berdampak pada arus utama migrasi pada kawasan Makassar dan kawasan Bulukumba yang keduanya menjadi memiliki migrasi neto yang negatif, sedangkan pada tiga kawasan lain migrasi netonya menjadi positif. Hasil simulasi S3 memberikan sinyal pentingnya penciptaan lapangan kerja baru di kawasan di luar kawasan Makassar dapat mengurangi arus migrasi masuk ke kawasan Makassar dan mengatasi kelebihan tenaga kerja (Adriani dan Wildayana, 2015).

Kebijakan S4 adalah pada dasarnya adalah kebijakan S3 ditambah peningkatan pengeluaran pemerintah daerah untuk kawasan Makassar, sehingga kebijakannya menjadi tanpa afirmasi. Dampak dari S4 terhadap peningkatan upah rata-rata, kesempatan kerja dan output secara umum menunjukkan hasil positif sama seperti simulasi S3, meningkatkan upah rata-rata sebesar 3.44 persen, kesempatan kerja 2.15 persen, dan output 2.57 persen. Namun secara spasial, S3 pengaruhnya pada kesempatan kerja masih negatif di kawasan Makassar, yakni sebesar -0.5 persen.

Dampak kebijakan S4 terhadap migrasi menunjukkan pola yang berbeda dengan S3. Kebijakan S4 meningkatkan migrasi masuk ke kawasan, termasuk kawasan Makassar meski hanya 0.89 persen. Sedangkan pada migrasi keluar, S4 menurunkan migrasi keluar pada kawasan Parepare sebesar -2.69 persen dan kawasan Bone -2.23 persen, namun meningatkan migrasi keluar di tiga kawasan lainnya. Peningkatan migrasi keluar terbesar pada kawasan Bulukumba mencapai 11.18 persen.

Hasil simulasi S4 menunjukkan dominannya kapasitas ekonomi kawasan Makassar dalam penciptaan lapangan kerja dan output dibandingkan kawasan lainnya sehingga menjadi dayatarik dan mendorong migrasi masuk dari kawasan lain. Karenanya perlu dan pentingnya melakukan perubahan kebijakan, strategi dan rencana pembangunan dan distribusi penduduk yang seimbang seperti dengan afirmasi terhadap kawasan pinggiran yang masih tertinggal pembangunannya. 


\section{SIMPULAN}

Kebijakan peningkatan upah minimum hanya menguntungkan pekerja yang mendapatkan peningkatan pendapatan, namun tidak bagi sebagian tenaga kerja lainnya karena berkurangnya kesempatan kerja. Kebijakkan upah minimum berdampak mengurangi kesempatan kerja dan output, serta meningkatkan arus migrasi masuk menuju ke kawasan Makassar. Kebijakan peningkatan upah minimum tidak menguntungkan bagi upaya pembangunan dan distribusi penduduk yang seimbang di Sulawesi Selatan jika tanpa disertai kebijakan lain. Untuk mengantisipasinya menjadi perlu dan penting untuk dilakuan kombinasi kebijakan upah minimum dengan afirmasi peningkatan pengeluaran pemerintah daerah pada kawasan di luar kawasan Makassar.

\section{DAFTAR PUSTAKA}

Adriani, D. dan Wildayana, E. (2015). Integrasi pertumbuhan Ekonomi dan Penciptaan Kesempatan Kerja Sektor Pertanian di Indonesia. Sosiohumaniora. 17 (3). 204-212.

Arman., Hadi, S., Achsani, NA. dan Fauzi, A. (2016). Analisis Sektor Strategis Pulau Sulawesi, Jawa Timur dan Kalimantan Timur. Sosiohumniora. 18 (2). 91-99.

Badan Pusat Statistik. (2011). Migrasi Internal Penduduk Indonesia Hasil Sensus Penduduk 2010. Jakarta: Badan Pusat Statistik.

(2016). Produk Domestik Regional Bruto Provinsi Sulawesi Selatan Menurut Pengeluaran 2011- 2015. Makassar: Badan Pusat Statistik Provinsi Sulawesi Selatan.

Bank Dunia. (2016). Ketimpangan yang Semakin Melebar. Jakarta: Tim Poverty Global Practice Bank Dunia.

Bird, K. and Manning, C. (2008). Minimum Wages and Poverty in a Developing Country: Simulations from Indonesia's Household Survey. World Development. 36 (5). 916-933.

Boffy-Ramirez, E. (2013). Minimum Wages, Earnings, and Migration. IZA Journal of Migration, ISSN 2193-9039, Springer, Heidelberg. 2. 1-24. http:// dx.doi.org/10.1186/2193-9039-2-17

Cadena, B. (2014). Recent Immigrants as Labor Market Arbitrageurs: Evidence from The Minimum Wage. Journal of Urban Economics 80 (2014). $1-12$.

Giulietti, C. (2014). Is The Minimum Wage a Pull Factor for Immigrants? Industrial and Labor Relations Review. 67(3). 649-674.
(2015). Do Minimum Wages Induce Immigration?. IZA World of Labor. 2015(151). doi:10.15185/ izawol.151

Harris, JR. and Todaro, MP. (1970). Migration, Unemployment and Development: A Two-sector Analysis. The American Economic Review. 60 (1). 126-142.

International Labour Organization. (2015). Labour and social trends in Indonesia 2014-2015. Jakarta: Strengthening competitiveness and productivity through decent work. ILO.

Izzaty dan Sari, R. (2013). Kebijakan Penetapan Upah Minimum Di Indonesia. Jurnal Ekonomi \& Kebijakan Publik. 4(2). 131-145.

Koutsoyanis, A. (1977). Theory of Econometrics: An Introductory Exposition of Econometric Methods. Second Edition. London: The Macmillan Press Ltd.

Khor, N. and Chun, N. (2010). Minimum Wages and Changing Wage Inequality in Indonesia. ADB Economics Working Paper Series No.196.

Lewis, WA. (1954). Economic Development with Unlimited Supplies of Labour. The Manchester School of Economic and Social. 22. 139-191.

Magruder, JR. (2013). Can Minimum Wages Cause a Big Push? Evidence from Indonesia. Journal of Development Economics, 100 (2013). 48-62. doi:10.1016/j.jdeveco.2012.07.003

Martin, D. and Termos, A. (2015). Does a High Minimum Wage Spur Low-skilled Emigration?. Economics Letters. 137(2015). 200-202.

Nyompa, S., Ali., N, MatJali, MF. dan Rostam, K. (2012). Aspek Sosial dan Ekonomi di Bandar Makassar, Sulawesi Selatan, Indonesia. Jurnal Perspektif 4(2). 85-98.

Pratomo, DS., dan Adi Saputra, PM. (2011). Kebijakan Upah Minimum untuk Perekonomian yang Berkeadilan: Tinjauan UUD 1945. Journal of Indonesian Applied Economics. 5(2). 269-285.

Pindyck, RS., and Rubinfeld, DL. (1991). Econometrics Model and Economics Forecast. New York: Third Edition. McGraw-Hill Inc.

Rama, M. (2001). The Consequences of Doubling The Minimum Wage: The Case of Indonesia. Industrial and Labor Relations Review. 54 (4). 864-881.

Santoso, AD., Sinaga, BM., Hartoyo, S., and Hutagaol, MP. (2017). Impact of Regional Government Expenditure and Investment on Internal Migration and Economy in Sulawesi Selatan, 
Indonesia. International Journal of Sciences: Basic and Applied Research (IJSBAR). 32(1). 169-180.

Stigler, GJ. (1946). The Economics of Minimum Wage Legislation. The American Economic Review. 36(3). 358-365.

Strobl, E., and Walsh, F. (2016). Monopsony, Minimum Wages and Migration. Labour Economics. 42. 221-237. http://dx.doi.org/10.1016/j. labeco.2016.09.004

Tim Presiden RI. (2016). 2 Tahun Pemerintahan JOKOWI-JK Akselerasi Mewujudkan Indonesia Sentris. Jakarta: Kantor Staf Presiden Republik Indonesia.
Todaro, MP. (1969). A Model of Labor Migration and Urban Unemployment in Less Developed Countries. The American Economic Review. 59(1). 138-148.

(1980). Internal Migration in Developing Countries: A Survey, in Population and Economic Change in Developing Countries. Richard A. Easterlin, ed. University of Chicago Press.

Todaro, MP., and Smith, SC. (2012). Economic development 11th ed. Boston: Pearson Education Inc.

Zavodny, M. (2014). Who Benefits from The Minimum Wage-Natives or Migrants?. IZA World of Labor. 2014(98). doi: 10.15185/izawol.98 